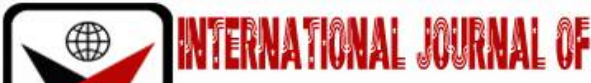

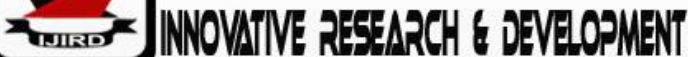

ISSN 2278 - 0211 (Online)

\section{Typology of Tourist Accommodation in the Borobudur Area, Indonesia}

\begin{tabular}{c} 
Aditha Agung Prakoso \\
Doctoral Student, Department of Architecture and Planning, \\
Gadjah Mada University, Indonesia \\
Eugenius Pradipto \\
Lecturer, Department of Architecture and Planning, \\
Gadjah Mada University, Indonesia \\
Muhammad Sani Roychansyah \\
Lecturer, Department of Architecture and Planning, \\
Gadjah Mada University, Indonesia \\
\hline
\end{tabular}

\section{Abstract:}

The village residential area surrounding Borobudur temple has a rapid growth. The tourism activity in the Borobudur area which has been appointed as a UNESCO World Heritage Site since 1991 gives significant impact for the growth of the surrounding area, especially for the residential area. One of the affected sectors is the dwelling houses. The increase of the tourists need in lodging availability pushes the dwelling houses in the Borobudur area to be developed as tourists' accommodation. This research aims to explain and group the changes appear from the development of dwelling houses to be tourist accommodation. Therefore, this research is able to find out the tourist accommodation typology in the Borobudur area based on the change happened in the dwelling houses. The method used is rationalistic qualitative research by using multiple case study in 3 villages in the Borobudur area, they are; Borobudur village, Candirejo, and Wanurejo.

Keywords: Typology, tourist accommodation, guesthouse, homestay, Borobudur

\section{Introduction}

Borobudur Temple is a cultural heritage building located in Borobudur Village, Borobudur District, Magelang Regency, Central Java, Indonesia. This site has been designated as a UNESCO cultural heritage site since 1991. In addition, this temple is also a cultural tourist attraction in Indonesia. In 2014, the Indonesian government designated the Borobudur Area as a national strategic area by the Indonesian government. Even in 2019, Borobudur is encouraged to become a super priority area for tourism. This opens wider tourists to visit Borobudur. According to statistical data, as many as 3.8 million tourists visited Borobudur Temple in 2017(BPS Kabupaten Magelang, 2018). The development of tourism in the Borobudur area has prompted changes in the houses around the tourist area to change their function to support tourism facilities. One of the obvious changes is the changing the function of residence to lodging for tourists. This is driven by the need for tourist accommodation, especially during school holidays, religious holidays (Eid and Vesak), and special events (performing arts and music, sports, and community activities).This impact is not only experienced by the area around the temple, such as the villages of Borobudur and Wanurejo, but also in other villages that organize tourism activities outside of temple tourism, such as nature tourism and rural tourism.

The phenomenon of changing the architecture of a residential house into a tourist house can be seen as: (1) a part of the process of improving a community in surviving and responding to the challenges it faces (Bukit et al., 2012); (2) the emergence of economic factors such as the provision of accommodation facilities for tourism activities is the most dominant factor in the changes of building (Rossi, 1984); and, (3) there is encouragement in the political aspect of regional development, in this case the development of the Borobudur tourist area (Setyaningsih, 2016). Uniquely, the development of tourist houses involving these residences has different characteristics. This is very much influenced by the respective determining factors, namely the factors of understanding or ideas of providers or managers of tourist houses, encouragement of local tourism organizations, knowledge and financial skills, and tourist needs. The uniqueness of the form and function characteristics of these tourist houses is what encourages researchers to classify tourist houses into a typology of tourist houses in the Borobudur area. Through this typological study, it is hoped that the grouping of tourist houses which is a changing from a residence due to the impact of tourism activities in the Borobudur area can be explained. So, this can be considered as the basis for planning a tourist house based on local values which is unique as a support for the development of tourist destinations. 
In recent years, there have been several studies explaining the typology of buildings, but findings about the typology of tourist accommodation in a tourism destination have not been described properly and clearly. (Rangkuty et al., 2019)explained the typology of Malay Chinatown building facades, regarding the character of the facade that still maintains regional identity. (Faisal et al., 2014)grouped of typical building door elements in the Sangiran Early Man Site conservation area. (Lihawa et al., 2006)researched the typology of Jaton houses which shows that the Jaton houses are very influenced by culture from inside (Java and Minahasa culture and outside (surrounding environment). (Jeraman, 2019)showed that the architecture of the Sabu house has distinctive characteristics that are in harmony with the Sabu culture. It has 3 typologies of houses in terms of form and function. From research on tourist accommodation, (Ismail et al., 2016; Luvandwa et al., 2020; Rizal et al., 2018) looking at the relationship between service quality, portals, facilities and visitor satisfaction, while (Junaid et al., 2019; Sukserm et al., 2020)seeing how strategies to support local communities through the development of tourist accommodation and (Swetha \& Srivinas, 2018)explain strategies to transform the homestay business into a sustainable business. From several studies on tourist accommodation, research needs to be enriched regarding the classification and categorization of tourist accommodation, especially those that develop from the idea of direct occupants, so that a typology of tourist accommodation can be obtained as a basis for planning targeted tourist accommodation.

\section{Literature Review}

Typology comes from the word Typos which means grouping and Logos which means knowledge or science, so that typology can be interpreted as a scientific field that studies or explains the grouping of an object. (Moneo, 1978) explains that typology is a concept that describes and elaborates a group of objects based on the similarity of their basic characteristics and an analysis of thinking based on their groups. So that it can be a tool for studying an architectural object. Furthermore, (Moneo, 1978)explains that typology analysis can be explained in 3 stages, including: (1) exploring history and describing the process of changing an architectural object; (2) describes the object's function; and (3) discovering its basic form and nature. (Guney, 2007)refers to the type of study which analyzes comparatively and classifies characteristics into certain types. This study becomes a basic way of thinking that enables two-way communication between logical science and social and cultural sciences. This research focuses on residential houses that are turned into tourist accommodation. This change is defined by (Habraken, 1983)as a process in an architectural object because of the controlling power (wants and needs) and aims to produce a new identity in order to survive and answer the challenges faced (sustainability). This sustainability is interpreted by (Rapoport, 1994)into 2 things, namely direct and indirect meaning. The meaning directly relates to cultural and social aspects, while the indirect meaning relates to fixed feature (shape, scale, build, organization, construction, material, and orientation).

\section{Methodology}

This research uses multiple case studies rationalistic qualitative method with 1 unit of analysis (tourist accommodation), so this research is included in the holistic multiple case study research. The research focus selected included 3 tourist villages in the Borobudur area, including: Borobudur Village, Candirejo Village and Wanurejo Village, all of which are in Borobudur District, Magelang Regency, Central Java Province. The databases used are primary and secondary data. Data from this study were collected from the results of field surveys by observing the history, facades, plans, and functions of buildings. Further analysis is described in terms of the relationship between the typology of tourist accommodation and users, functions, plans and facades. Analysis is also carried out by drawing plans and classifying building types and their changes so as to obtain a research finding.

\section{Area of Study}

The selected area of study covering three villages in the Borobudur area, they are; Borobudur village, Candirejo, and Wanurejo. located in the District of Borobudur, Magelang Regency, Central Java Province.

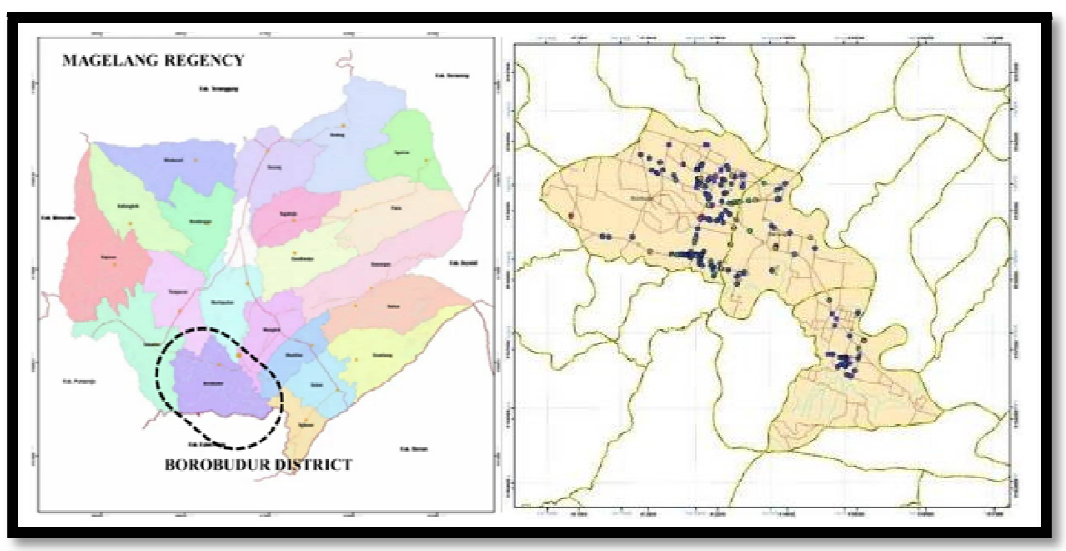

Figure 1: Map of Area of Study and Accommodation Distribution Source: Magelang Regency and Observation, 2019 


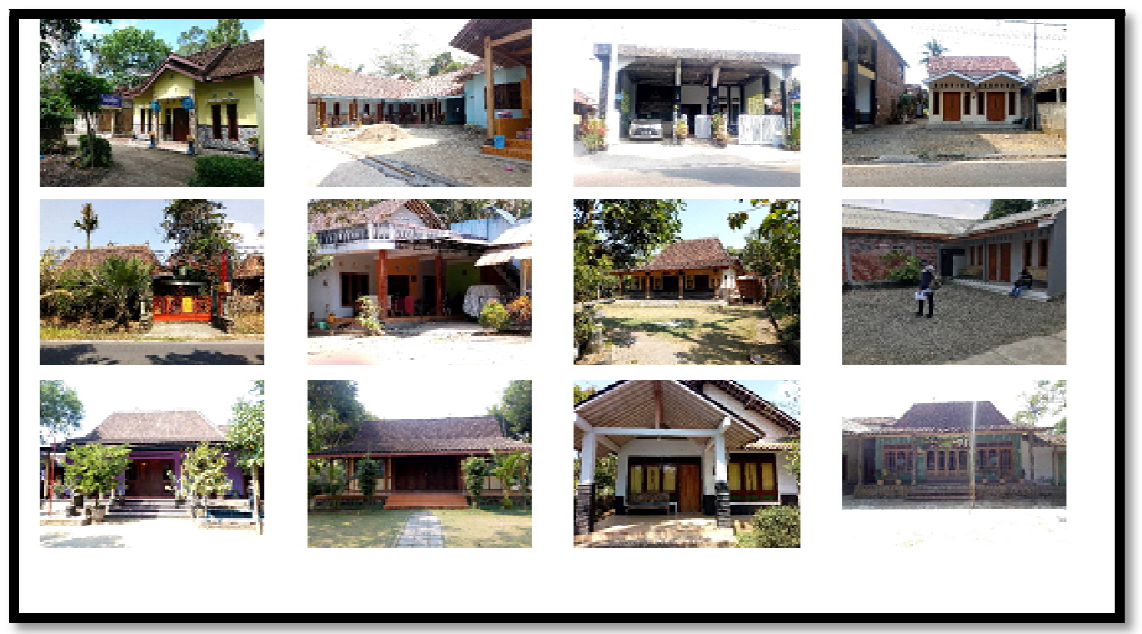

Figure 2: Tourism Accommodations Building in the Borobudur Area Source: Observation, 2019

\section{Result and Discussion}

The research location was focused on the villages that grew rapidly in the development of tourist houses in the Borobudur area, so that the research locations were set in 3 villages, namely Borobudur, Candirejo and Wanurejo Villages. Borobudur and Wanurejo Villages are areas that are directly affected by the existence of Borobudur and Pawon Temples, while Candirejo Village develops the area as a rural tourism area, with lodging objects located in the main corridor of temple tourism and supporting corridors, including:

- Borobudur Village: Balaputeradewa, Badrawati, MedangKamulan, dan Borobudur - Ngadiharjo Road

- Wanurejo Village: Balaputeradewa, Brojonalan, Barepan, dan Jowahan Road

- Candirejo Village: Borobudur - Nanggulan, Sangen, Margonodadi dan MangundadiRoad

According to(Habraken, 1983)chronological changes can be explained using chronological changes in physical entities from their initial form to their current form, with regard to the changer agents involved in the transformation. Thus, the process of studying residential change becomes defined from the identification of its initial form, process and current form by looking at the actors and activities that influence the change. Analysis will also be carried out diachronic to identify and select tourist accommodation that develops from residential houses.

\subsection{Typology Base on Building Function}

The tourist accommodation building that is studied is a building that initially functions as a residence or an accommodation from the expansion of the main house which is still in one land. Data collection was carried out by direct interviews with community leaders who know the history of the development of the area and to residents or managers of tourist accommodation. From the results of these observations and interviews, several classifications of tourist accommodation based on the function of the building can be found, including:

- Type of impromptu tourist accommodation is a residence that suddenly turns into tourist accommodation, when there is a tourist demand for accommodation needs. This occurs during holidays (Eid) and school holidays (in June - August) as well as when major activities are held in the Borobudur area, such as the Borobudur Marathon and Vesak.

- Type of homestay I is a residence where part of the space is used as a room for tourists.

- Type of homestay II is a residence where part of the land is used as a building / tourist room. Types of tourist houses I and II have something in common that they are still connected directly to the main house.

- Type of guesthouse I is a residence that has been permanently converted as tourist accommodation and is separated from its connection with the main house or its original occupants.

- Type of guesthouse II is functionally as the same as type of guesthouse I, but in marketing it has collaborated with existing tourist accommodation networks (OYO, Reddoorz dan Airy).

\subsection{Typology Base on Building Transformation}

The development of the plan is quite significant. It can be seen from the change in function from a residence to a tourist accommodation. The depiction of building plans is generalized by looking at the function of the residential space which turns into other function.

- Developed type, in this type there is a development of house plans with the addition of guest accommodation function in the building and residential land. The developed type can be divided into 3 models, including:

Function development, in this type, the development of the function to become tourist accommodation occurs when there is an empty bedroom or additional space which is prepared as a guest / tourist room. This development still utilizes the house space which is still spacious. 


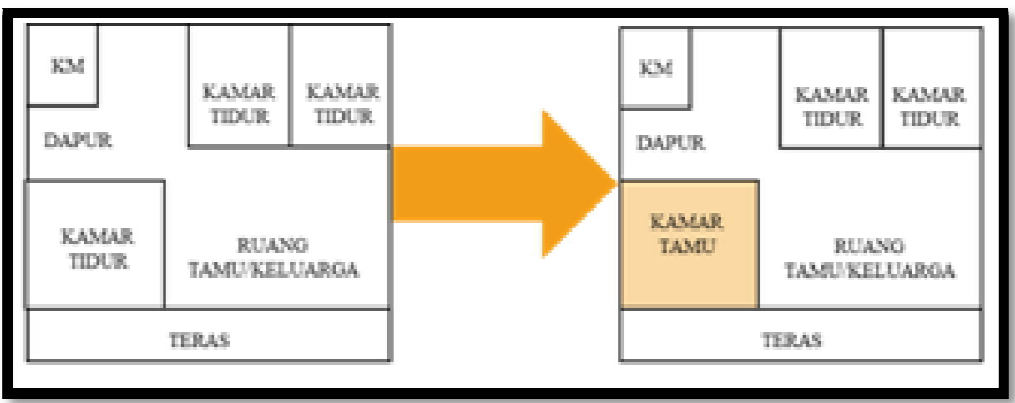

Figure 3: Function Development

- Plans and Facades Development is to accommodate the function of accommodation. The home owner adds a new space that is used as a room and bathroom for guests. The new space is still attached to the main building and provides another look to the building plans and facades.

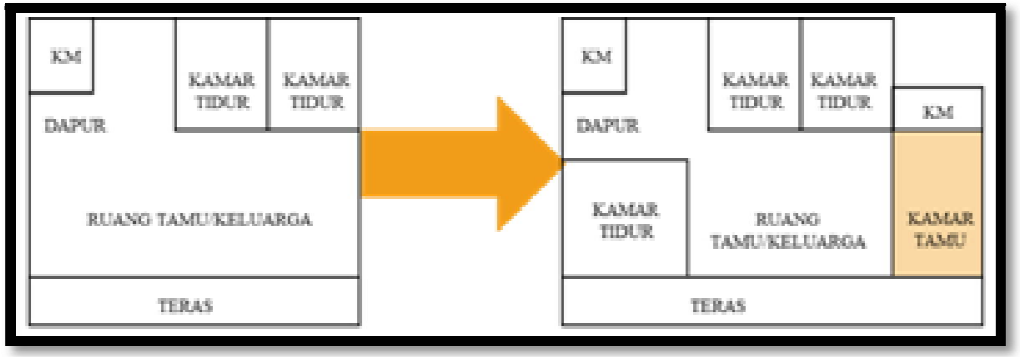

Figure 4: Plans and Facades Development

- Building Development, the new accommodation function is carried out by utilizing the house land which is still wide, so that a new building is built, but is still one land and is directly connected to the main house.

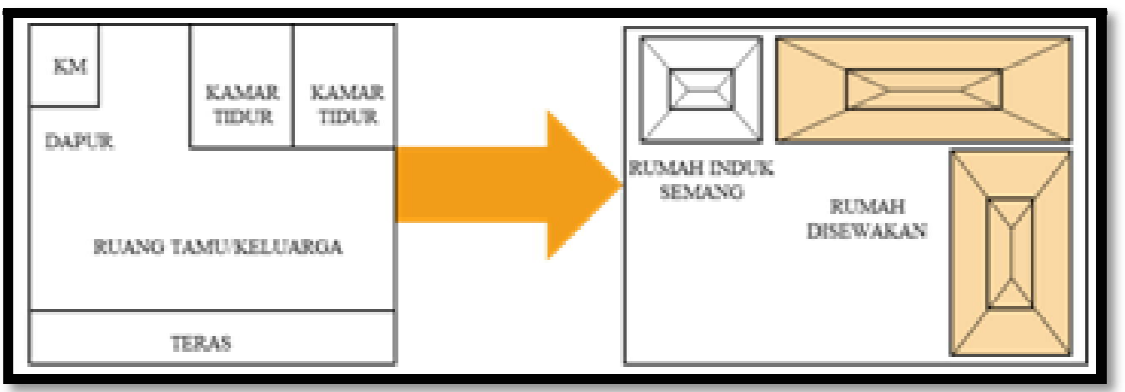

Figure 5: Building Development

- Changed type, in this type there is a complete building change, both only in function and in function and form. The type of change can be divided into 2 models, including:

Permanent change, there are regular and comprehensive changes in residential buildings. The initial building is renovated and changed in function and form to accommodate a new function, namely as tourist accommodation. In general, residents will move or build new houses on other land. Buildings with this type of change generally also become network-based tourist accommodation buildings in collaboration between accommodation owners and accommodation networks to manage and market their accommodation.

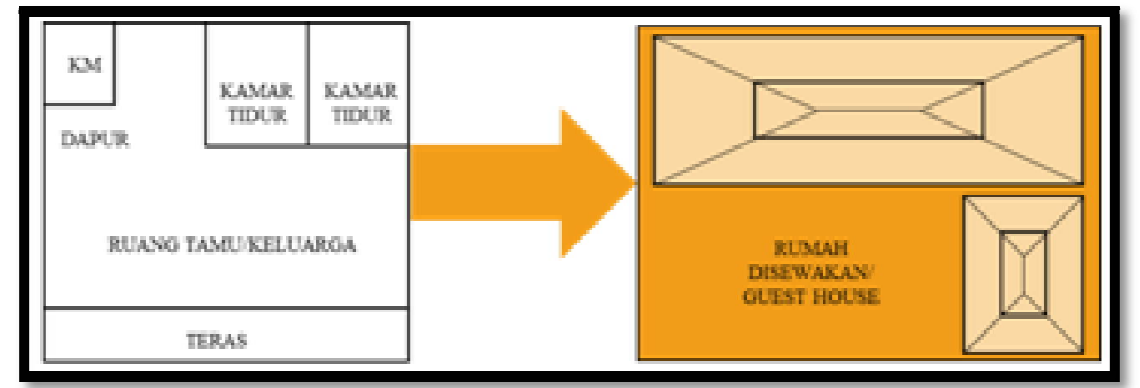

Figure 6: Permanent Change 
Temporary change, this change represents an alteration in the overall function of a residential house into temporary tourist accommodation. This condition is usually found in the certain time (such as holiday and big event) and at the time the accommodations are fully booked. As the result there is a demand for accommodation which is used by local residents as an impromptu business opportunity.

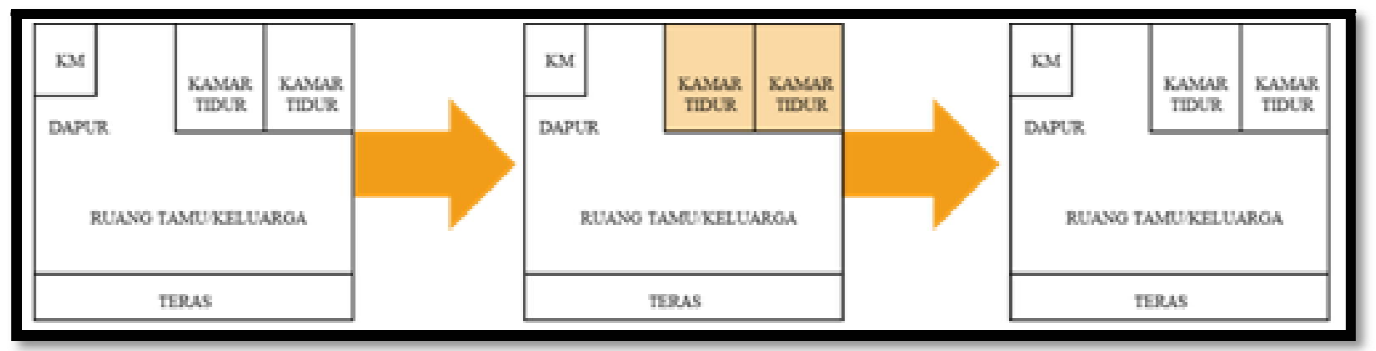

Figure 7: Temporary Change

\subsection{Typology Base on Building Distribution}

Based on 3 research location, the distribution of tourist accommodation in the Borobudur area can be mapped, thus the aim of this activity is to see the distribution zone based on the analysis result of function, shape, and map, then it describes the lodging forms in the research location with an understanding of the form of lodging as follows.

- Accommodation Type A - Homestay, tourist accommodation which still be used as home living (at the same house or the same land), so that there is still a direct interaction between the residents and the guests.

- Accommodation Type B - Guesthouse, tourist accommodation which specifically used as tourism resort, apart from the residents.

- Accommodation Type C - Network-based accommodation, tourist accommodation which is specifically used as tourism resort, apart from the residents, and have collaborated with existing tourist accommodation networks.

- Accommodation Type D - Impromptu tourist accommodation, house living tourist accommodation which has 1 or 2 empty rooms, which suddenly functioned as a guest or tourist room.

- The following is a mapping of the distribution and description of the conditions of tourist accommodation at the research location

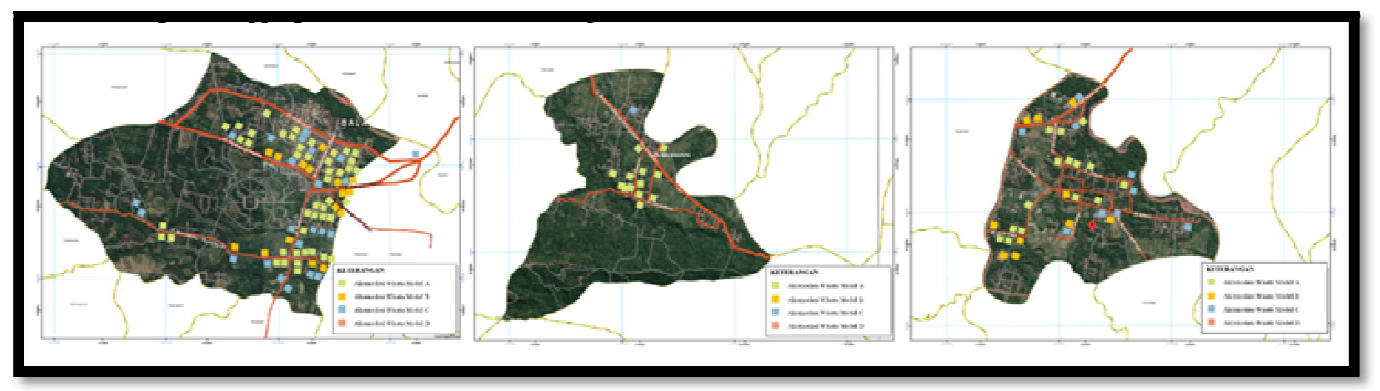

Figure 8: Distribution of Tourist Accommodation in Area of Study Source: Observation, 2020

\subsubsection{Borobudur}

Borobudur village is an area where Borobudur Temple stands and it is the center of tourist activities in Borobudur area. Therefore, this village has a various accommodation from stars hotel, resort, guesthouse and homestay which spread along Balaputeradewa, Badrawati, Medang Kamulan, Borobudur - Ngadiharjo street and the neighborhoods. From the result of further research on the tourist corridors in Bodobudur village, it is found (1) the corridor in the main resort (Balaputeradewa, Badrawati, MedangKamulan, Borobudur - Ngadiharjo street) is dominated by tourist accommodation type B and C, meanwhile, some type A accommodation is on the knot of Badrawati and Borobudur - Ngadiharjo which is a pioneering accommodation in Borobudur; meanwhile (2) on the supporting corridors (alleyway) especially Ngaran I and II, Gendingan, Janan, Kurahan and some in Gopalan, there are some type A and has a potential to rise type D.

\subsubsection{Candirejo}

Candirejo village is one of the pioneering villages in the development of rural tourism or tourism villages in the Borobudur area, this village, which officially became a tourist village in 2003, developed tourist accommodation from residents' homes became tourist lodgings. This tourist accommodation appears as a support from residents in developing tourism activities in Candirejo which require tourist accommodation facilities in the tour packages offered. With the assistance form Koperasi (Cooperative) Candirejo Tourism Village as the sole manager of tourism activities, residents' houses are prepared as accommodation while maintaining the framework of local norms, beliefs and traditions. Therefore, the tourism accommodation developed is a model A tourist accommodation or a tourist house, so that for tourists, they can interact directly with local residents and get a unique tourism experience, also tourists' behavior can be well maintained in the village environment. The distribution of tourist accommodation in Candirejo is scattered in rural residential areas, depending on the readiness and suitability of the house as a homestay. 


\subsubsection{Wanurejo}

Wanurejo is a village directly adjacent to the village of Borobudur, apart from being directly affected by the tourism activities around the temple, Wanurejo Village is also the village where Pawon Temple is located. The development of Wanurejo focuses on its support as a supporting area for tourism activities with Borobudur Temple as the center of activities, so that the development of tourist accommodation in this village is an expansion of tourist space centered on Borobudur Temple. From the further research in the tourism corridors in Wanurejo village, it is found out: (1) the corridor in the main resort (some of Balaputeradewa street and Nanggulan - Borobudur street) is dominated by accommodation type B and C; meanwhile (2) on the supporting corridors (alleyway) especially Brojonalan, Barepan and Jowahan, there are accommodation type $\mathrm{A}$ and has a potential to rise type $\mathrm{D}$.

From the research finding, Borobudur village and Wanurejo have accommodation type A, B and C, meanwhile, Candirejo village only has type A. Besides all those types, it is found impromptu tourist accommodation models of residential houses that appear during holidays (Eid) and school holidays (in June - August) as well as when major activities are held in the Borobudur area, such as the Borobudur Marathon and Vesak. This impromptu tourist accommodation (Type D) is a house which has 1 or 2 empty rooms, which suddenly functioned as a guest or tourist room. So that this residence changed its function temporarily to become a tourist accommodation type A when the demand for accommodation was booming and tourist accommodation in the Borobudur area was full, this model appeared in the villages of Borobudur and Wanurejo. This is the basis for determining the distribution of tourist accommodation types in the Borobudur area which are divided into several zones, including:

- The Guesthouse Zone (including those based on networks) is dominated by the main road corridors of the area, especially those near the location of Borobudur Temple.

- The Homestay Zone is on the next layer of Borobudur Temple, still on the main road corridor and some on the village road and still close to supporting attractions and tourism support facilities in the area, and

- The Impromptu Tourist Accommodation Zone is in the third layer area and tends to be in the corridor of the village road.

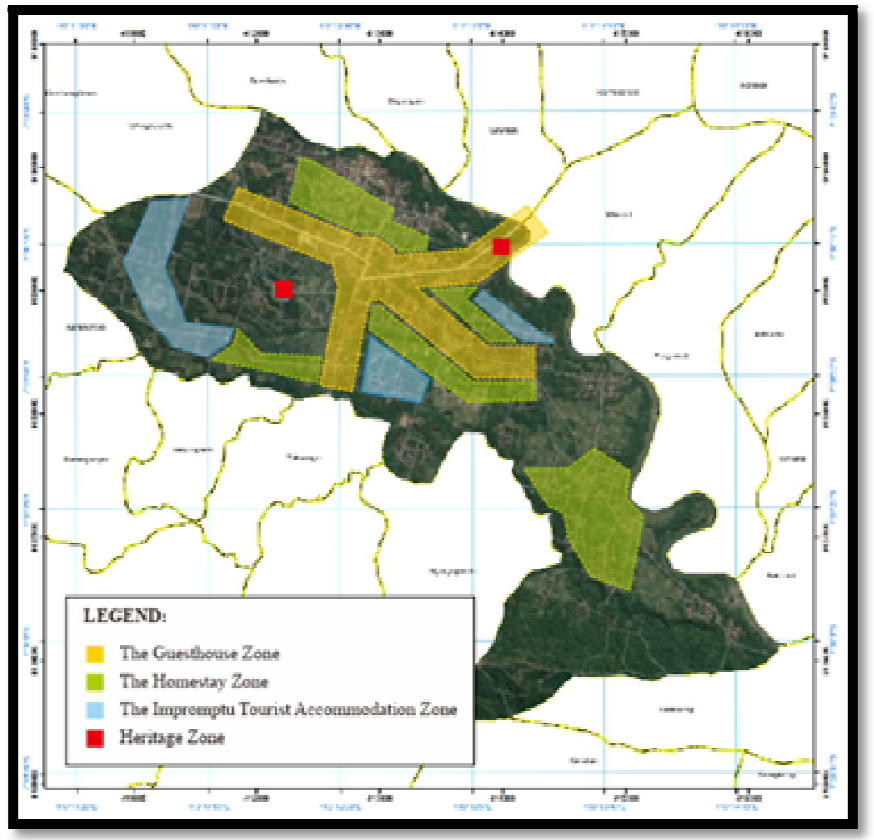

Figure 9: Distribution Zone of Tourist Accommodation in Borobudur Area

Source: Analysis, 2020

\section{Conclusion}

This typology classification of tourist accommodation in the Borobudur area will explain the knowledge on changing that occur in residential houses to realize new functions and forms of tourist accommodation, as the findings of this study.

- Based on the typology of its function, tourist accommodation in the Borobudur area can be divided into 2, namely tourist accommodation that still maintains the function of residence for its residents, as well as tourist accommodation that has completely changed and left its original function as a residence.

- The transformation of tourist accommodation buildings that appears is the transformation of its form and function, both permanent and temporary.

- This development is also influenced by the location of the building, there has been a trend towards comprehensive development, with changes in form and function that have left the function of houses in zones close to the center of tourist activities, in this case Borobudur Temple.

From the findings in the field, the development of residential buildings into tourist accommodation is strongly influenced by economic factors. Tourism activities that raise the needs of tourists that occur in the Borobudur area, 
encourage local residents to seize opportunities and convert them into economic benefits that can improve their welfare. The follow-up of this research is to be able to explain the further development of tourist accommodation in the Borobudur area since the Borobudur area has become a super-priority area for Indonesian tourism and there has been intervention by the Indonesian government in the development of tourist accommodation in the area, especially in residential buildings and the distribution of planning which is increasingly widespread. and spread from Borobudur Temple.

\section{References}

i. BPS Kabupaten Magelang. (2018). Statistik Daerah Kabupaten Magelang 2018. Badan Pusat Statistik Kabupaten Magelang.

ii. Bukit, E. S., Hanan, H., \& Wibowo, A. S. (2012). Aplikasi Metode N . J . Habraken pada Studi Transformasi. Jurnal Lingkungan Binaan Indonesia V, 1(1), 51-62.

iii. Faisal, G., Wihardyanto, D., \& Roychansyah, M. S. (2014). Tipologi Pintu Rumah Tradisional Dusun Pucung, Situs Manusia Purba Sangiran. Langkau Betang: Jurnal Arsitektur, 1(2), 65-73. https://doi.org/10.26418/lantang.v1i2.18801

iv. Guney, Y. I. (2007). Type and Typology in Architectural Discourse. BAÜ FBE Dergisi, 9(1), 3-18. http://fbe.balikesir.edu.tr/dergi/20071/BAUFBE2007-1-1.pdf

v. Habraken, N. J. (1983). Transformations of The Site. MIT Press.

vi. Ismail, M. N. I., Hanafiah, M. H., Aminuddin, N., \& Mustafa, N. (2016). Community-based Homestay Service Quality, Visitor Satisfaction, and Behavioral Intention. Procedia - Social and Behavioral Sciences, 222, 398-405. https://doi.org/10.1016/j.sbspro. 2016.05.192

vii. Jeraman, P. (2019). Tipologi Arsitektur Rumah Sabu (Ammu Hawu), Sebuah Pendekatan Deskriptif Antropologis. Jurnal Arsitektur KOMPOSISI, 12(3), 225. https://doi.org/10.24002/jars.v12i3.2204

viii. Junaid, I., Salam, N., \& Salim, M. A. M. (2019). Developing homestay to support community-based tourism. Masyarakat, Kebudayaan Dan Politik, 32(4), 390. https://doi.org/10.20473/mkp.v32i42019.390-398

ix. Lihawa, H. R., Suwarno, N., \& Nuryanti, W. (2006). Tipologi Asitektur Rumah Tinggal Studi Kasus Masyarakat Jawa Tondano (Jaton) Di Desa Reksonegoro Kabupaten Gorontalo. Jutap UGM, 1-15.

x. Luvandwa, K. F., Damiannah, K., \& Odiara, K. B. (2020). Effects Of Service Reliability On Guests' Satisfaction With Homestay Facilities In Nyeri And Laikipia Counties, Kenya. International Journal of Business Management \& Finance, 3(2), 258-274.

xi. Moneo, R. (1978). Oppositions (pp. 23-45). The MIT Press.

xii. Rangkuty, G., manda Utami, \& Widyastuti, D. T. (2019). Architectural Typology of the Malay Chinatown Facade ( Case: Perniagaan Street of Malay Chinese Village Bagansiapiapi, Rokan Hilir, Riau). International Journal of Architecture and Urbanism, 03(01), 95-110.

xiii. Rapoport, A. (1994). Sustainability Meaning and Traditional Environments. In University of California (Ed.), Traditional Dwellings and Settlements Working Paper Series (75th ed.). Center for Environmental Design Research.

xiv. Rizal, H., Amin, H., Yussof, S., Chen-Jung, K., Lada, S., \& Nasirin, S. (2018). User Satisfaction Of E-Homestay Portals In Malaysia. Labuan Bulletin of International Business \&Finance, 16(1), 1-14.

xv. Rossi, A. (1984). Architecture of The City. MIT Press.

xvi. Setyaningsih, W. (2016). Transformasi Arsitektural dari Kampung Kota Menjadi Kampung Wisata. Gadjah Mada University.

xvii. Sukserm, T., Udomphan, P., Jaksil, D., \& Sutthiprapa, W. (2020). Positioning Strategy of Homestay Business : A Case Study 3 communities in Ubon Ratchathani and Amnat Charoen Provinces. International Journal of Development Administration Research, 4(1), 31-41.

xviii. Swetha, P. A., \& Srivinas, K. T. (2018). TBL Model For Homestay's Sustainability. Abhinav National Monthly Refereed Journal of Research in Commerce \& Management, 7(3), 29-33. 